\title{
Cobalamins in Fibroblasts Cultured from Normal Control Subjects and Patients with Methylmalonic Aciduria
}

\author{
JOHN C. LINNELL, DAVID M. MATTHEWS, S. HARVEY MUDD, ${ }^{(36)}$ B. WILLIAM UHLENDORF, \\ AND IRENE J. WISE

\begin{abstract}
Department of Experimental Chemical Pathology, The Vincent Square Laboratories of Westminister Hospital, London, England, and the Laboratory of General and Comparative Biochemistry, National Institute of Mental
\end{abstract} \\ Health, Bethesda, Maryland, USA
}

Extract

The intracellular content and proportional distribution of $\mathbf{B}_{12}$ (cobalamin) derivatives in fibroblasts cultured from patients with various forms of methylmalonic aciduria, as well as from normal control subjects, has been determined by a two-dimensional chromatobioautographic technique. Each line of fibroblasts was grown in the presence of four concentrations of cobalamin, ranging from the $0.04-0.07 \mathrm{pmol} / \mathrm{ml}$ contained in the basal medium to 74 $\mathrm{pmol} / \mathrm{ml}(100 \mathrm{ng} / \mathrm{ml})$, added in form of hydroxocobalamin $(\mathrm{OH}$ $\mathrm{CBI}$ ). Control cells grown in the basal medium contained substantial proportions of both methylcobalamin $(\mathrm{MeCbl})$ and adenosylcobalamin (AdoCbl), with the former predominating. As increasing concentrations of $\mathrm{OH}-\mathrm{CBl}$ were added to the growth medium, the total cellular cobalamin content increased without marked changes in the relative proportions of $\mathrm{MeCbl}$, Ado $\mathrm{Cbl}$, and $\mathrm{OH}-$ Cbl. Three different patterns were discernable in the cobalamin distributions of the cells cultured from patients with methylmalonic aciduria (Table 1 and Fig. 1).

\section{Speculation}

Information about the cobalamin contents of cultured fibroblasts yields further understanding of cobalamin metabolism. Such information, obtained by the technique of two-dimensional chromatobioautography, permits definition of genetically determined abnormalities in the handling of cobalamins, as well as examination of possible correlations between cellular responses to increased concentrations of these compounds and the effectiveness of cobalamins in the clinical treatment of patients.

In recent years a number of patients have been described who suffer from inborn errors affecting the activity of one or both of the enzymes which in mammals are known to require cobalamin $(\mathrm{Cbl})$ derivatives as coenzymes. Most frequently reported have been patients with methylmalonic aciduria due to deficient activity of methylmalonyl-CoA CoA-carbonylmutase (methylmalonyl-CoA mutase, EC 5.4.99.2). Such patients may either have a defective mutase apoenzyme, or may be unable to accumulate normal amounts of the coenzyme, AdoCbl $(20,28)$. The latter group has recently been further divided on the basis of whether or not cell extracts are able to carry out normal synthesis of AdoCbl when incubated anaerobically with OH-Cbl, ATP, FAD, and dithiothreitol (15). A less frequently reported group of patients exhibit both methylmalonic aciduria, and homocystinuria due, respectively, to lack of activity of methylmalonyl-CoA mutase and of 5-methyltetrahydrofolate-homocysteine methyltransferase (EC 2.1.1.13) $(3,6,23-25)$. The latter enzyme requires $\mathrm{MeCbl}$ as cofactor. The tissues of these patients accumulate neither AdoCbl nor $\operatorname{MeCbl}(3,17,23)$. Thus, there is ample evidence that the heterogeneous group of patients with methylmalonic aciduria includes several subgroups with various abnormalities in the metabolic handling of cobalamins.

A newly developed technique which has proven useful for gaining insight into many aspects of cobalamin metabolism is that of two-dimensional chromatobioautography $(11,13,14)$. This method permits the sensitive and specific determination of individual cobalamin derivatives in small samples of plasma or tissue. We have applied this technique to the study of cobalamins in fibroblasts.cultured from patients with various forms of methylmalonic aciduria. In this paper we report the results of this study, as well as the results of cobalamin analyses of fibroblasts cultured from normal control subjects.

\section{METHODS}

Cultures were initiated from skin biopsies and fibroblasts were grown and harvested as described previously (25). The same lot of serum supplement for the culture medium was used throughout. For studies of the effect of added $\mathrm{OH}-\mathrm{Cbl}$, cells were grown in complete darkness either in the presence of basal medium (containing $0.04-0.07 \mathrm{pmol} / \mathrm{ml} \mathrm{Cbl}$ ), or in the same basal medium with $\mathrm{OH}-\mathrm{Cbl}$ added as specified in the individual experiments. The cells were re-fed after 2 and 4 days, and on day 5 they were harvested under the illumination provided by a 25 -watt red bulb (Westinghouse) filtered through a Kodak safelight \#1 A filter and a Wratten no. 70 filter. Cells were counted by use of a Coulter counter. For estimation of fibroblast cobalamins, the weighed cell pellet was dispersed in $5 \mathrm{ml}$ water, and a $2-\mathrm{ml}$ aliquot was taken for the estimation of AdoCbl, $\mathrm{MeCbl}, \mathrm{OH}-\mathrm{Cbl}$, and $\mathrm{CN}-\mathrm{Cbl}$ by a two-dimensional chromatobioautographic method (13, 14). Precuations were taken to avoid exposure of samples to light. Total vitamin $B_{12}$ was estimated on $1-\mathrm{ml}$ aliquots of cell suspension by a radioisotopic assay (19). Total nitrogen was estimated by an automated micro-Kjeldahl method (30) using a continuous digester and a modified digestion mixture of $95 \%$ sulfuric acid containing $30 \mathrm{~g}$ selenium dioxide and $10 \mathrm{ml}$ perchloric acid/liter (9)

\section{SUBJECTS}

The control lines of fibroblasts used were obtained from healthy individuals free of known metabolic abnormalities. These fibroblasts had been included as normal controls in previous studies of the rates of conversion of $\left[1-{ }^{14} \mathrm{C}\right]$ propionate to ${ }^{14} \mathrm{CO}_{2}$ by intact cells, and of the activities of 5-methyltetrahydrofolate-homocysteine methyltransferase in cell extracts (25) and were comparable with other control cell lines in these respects.

Cells were studied from six patients with methylmalonic aciduria. The available evidence suggests that these patients fall into at least three groups classified as follows. 
GROUP $a$ : DEFECTIVE METHYLMALONYL-COA MUTASE APOENZYME

$M O$, male, died at 5 months. Cultured fibroblasts had a normal activity of 5-methyltetrahydrofolate-homocysteine methyltransferase, but failed to convert $\left[1{ }^{14} \mathrm{C}\right]$ propionate to ${ }^{14} \mathrm{CO}_{2}$ at a normal rate (present studies). Morrow and coworkers (21) have shown that extracts of cultured fibroblasts and of liver have little or no detectable activity of methylmalonyl-CoA mutase even in the presence of added AdoCbl (21).

\section{GROUP $b$ : FAILURE TO ACCUMULATE AdoCbl}

$K B$ was a female who died at 5 weeks. Morrow et al. (21) have demonstrated that cultured fibroblasts metabolize propionate abnormally slowly. Extracts of fibroblasts and liver have low activities of methylmalonyl-CoA mutase in the absence of added AdoCbl, but normal activities in the presence of added AdoCbl. The cultured cells fail to accumulate normal amounts of $\left[{ }^{57} \mathrm{Co}\right]-$ AdoCbl when grown in the presence of $\left[{ }^{57} \mathrm{Co}\right] \mathrm{OH}-\mathrm{Cbl}(21)$. Fibroblast extracts fail to synthesize $\mathrm{AdoCbl}$ when incubated in an $\mathrm{H}_{2}$ atmosphere with ATP, $\mathrm{MgCl}_{2}, \mathrm{OH}-\mathrm{Cbl}$, dithiothreitol, and FAD. Under these conditions extracts of control fibroblasts form AdoCbl (15).

\section{GROUP $c$ : FAILURE TO ACCUMULATE EITHER AdoCbl OR MeCbl}

$E M$, a male, died at 7.5 weeks with methylmalonic aciduria and homocystinuria (10). Cultured fibroblasts have defects in propionate oxidation and homocysteine methylation which are (at least partially) repaired by growth in the presence of high concentrations of $\mathrm{OH}-\mathrm{Cbl}$. 5-Methyltetrahydrofolate-homocysteine methyltransferase activity in fibroblast extracts was very low in the absence of added $\mathrm{MeCbl}$, but almost normal in the presence of added $\mathrm{MeCbl}$ (25). Liver and kidney contained abnormally low concentrations of AdoCbl (23). Fibroblasts grown in the presence of $\left[{ }^{37} \mathrm{Co}\right] \mathrm{OH}-\mathrm{Cbl}$ failed to accumulate normal concentrations of either $\left[{ }^{57} \mathrm{Co}\right] \mathrm{AdoCbl}$ or $\left[{ }^{57} \mathrm{Co}\right] \mathrm{MeC} b l(17)$.

$M M$, a female child, died at 7 years with methylmalonic aciduria and evidence of disturbed homocysteine metabolism. Liver extracts converted methylmalonyl-CoA to succinate abnormally slowly unless AdoCbl was added. 5-Methyltetrahydrofolatehomocysteine methyltransferase activity in fibroblast extracts was very much below normal unless $\mathrm{MeCbl}$ was added. Liver, kidney, spleen, and brain contained abnormally low concentrations of all forms of cobalamins (3).

$J R$, a male, now 19 years, had methylmalonic aciduria and homocystinuria. No defect in propionate oxidation was demonstrable in intact cultured fibroblasts $(6,8)$. 5-Methyltetrahydrofolate-homocysteine methyltransferase activity in fibroblast extracts was abnormally low without added $\mathrm{MeCbl}$, but virtually normal with added $\mathrm{MeCbl}(6)$.

$M R$, a male child, now 8 years, had methylmalonic aciduria and homocystinuria, and was a brother of $J R$. Findings with cultured fibroblasts were essentially the same as with fibroblasts of $J R(6)$.

\section{RESULTS}

For the present studies, each line of fibroblasts was grown in the presence of four concentrations of cobalamin, ranging from the $0.04-0.07 \mathrm{pmol} / \mathrm{ml}$ contained in the basal medium, to $74 \mathrm{pmol} / \mathrm{ml}$ $(100 \mathrm{ng} / \mathrm{ml})$, added in the form of $\mathrm{OH}-\mathrm{Cbl}$. Each cell preparation was analyzed for total colbalamin content, and, by two-dimensional chromatobioautography, for the specific derivatives, AdoCbl, MeCbl, OH-Cbl, and cyanocobalamin (CN-Cbl). The results, expressed as cobalamin content per $10 \mathrm{mg}$ cellular nitrogen, are presented in Table 1. In this table, the indivudual compounds are given also as percentages of total cellular cobalamin. For some cell lines, more than one experiment was carried out. The values entered are the means of the individual experiments. Three lines of fibroblasts from normal control subjects were studied. The values are listed as means $\pm 1 \mathrm{SD}$.
These control cells, when grown in the basal medium, contained substantial proportions of both $\mathrm{MeCbl}$ and $\mathrm{AdoCbl}$, with the former predominating. As increasing concentrations of $\mathrm{OH}-\mathrm{Cbl}$ were added to the growth medium, the total cellular cobalamin content increased progressively, up to approximately 20 -fold the concentration under basal conditions. The changes in the individual cobalamins were approximately commensurate, so that the percentage distributions of $\mathrm{MeCbl}$, AdoCbl, and $\mathrm{OH}-\mathrm{Cbl}$ did not change markedly. Under no circumstances were significant amounts of $\mathrm{CN}$-Cbl detected in the control cells. When the data were expressed in terms of cell number, rather than on the basis of cellular nitrogen (Fig. 1), the patterns of cobalamin concentration were similar. The slight differences which were present do not affect any of the substantive conclusions arrived at subsequently in this presentation.

Three different patterns of response were discernable in the cells cultured from patients with methylmalonic aciduria, as can be seen in Table 1 and Figure 1, and described as follows.

\section{FIBROBLAST LINES}

Group a. One fibroblast line, that from $M O$, had no apparent abnormality in cobalamin accumulation. Total $\mathrm{Cbl}, \mathrm{MeCbl}$, $\mathrm{AdoCbl}$, and $\mathrm{OH}-\mathrm{Cbl}$ were essentially within normal limits, and increased normally as $\mathrm{OH}-\mathrm{Cbl}$ was added to the growth medium.

Group $b$. One line of cells, that from $K B$, contained virtually no AdoCbl under any of the cultural conditions. In these cells the $\mathrm{MeCbl}$ contents and proportions were higher than normal, the $\mathrm{OH}-\mathrm{Cbl}$ below normal, but the total cobalamin concentrations were in the normal range.

Group $c$. Four cell lines, those from $E M, M M, J R$, and $M R$, had multiple abnormalities. Each of these lines had decreased concentrations and decreased proportions of $\mathrm{MeCbl}$, although this trend was less marked for cells from $J R$ and $M R$, especially when the cells were grown at low concentrations of cobalamin. As OH-Cbl was added to the growth medium, $\mathrm{MeCbl}$ concentrations increased. The proportions of this compound remained approximately the same. Thus, cells grown at the highest concentration of $\mathrm{OH}-\mathrm{Cbl}$ contained as much, or more MeCbl than did normal control cells grown in the basal medium.

Similar patterns were seen for the cellular concentrations of AdoCbl. For this compound, the deficits in concentrations appeared to be less severe, and the proportions were on the whole normal. Again, the cellular AdoCbl concentrations rose as $\mathrm{OH}$ Cbl was added to the growth medium. In three instances, a medium concentration as low as $7.4 \mathrm{pmol} / \mathrm{ml}$ led to cellular concentrations higher than the mean for control cells grown in the basal medium.

These cell lines had low or low normal concentrations of $\mathrm{OH}-\mathrm{Cbl}$. The net results of all these changes were decreased cellular concentrations of total $\mathrm{Cbl}$.

It was only in cells among this group (and in single samples from $K B$ and $M O$ ) that significant amounts of $\mathrm{CN}-\mathrm{Cbl}$ were detected. In no instance was the proportion of this compound more than $13 \%$ of the total $\mathrm{CbI}$ ( $M R$ cells grown in basal medium). The presence of $\mathrm{CN}-\mathrm{Cb}$ was not observed consistently in repeated experiments.

\section{DISCUSSION}

The results reported here are, to our knowledge, the first complete analyses of cobalamin concentrations and distributions in cultured human fibroblasts. For control cells grown in our basal medium we find mean concentrations of $0.67 \mathrm{pmol} \mathrm{MeCbl} / 10^{8}$ cells and $0.34 \mathrm{pmol} \mathrm{AdoCbl} / 10^{8}$ cells. Since approximately $2 \times$ $10^{8}$ cells comprise $1 \mathrm{~g}$ wet weight, these values are equivalent for $\mathrm{MeCbl}$ and $\mathrm{AdoCbl}$, respectively, to 1.34 and $0.68 \mathrm{pmol} / \mathrm{g}$ wet weight cells. Addition of $0.74 \mathrm{pmol} / \mathrm{ml} \mathrm{OH}-\mathrm{Cbl}$ to the growth medium brought about rises in these concentrations to 2.24 and $1.66 \mathrm{pmol} / \mathrm{g}$. These values may be compared with those reported by Mahoney and coworkers using a radioisotopic technique (16, 17). For control human fibroblasts grown in basal medium 
FIBROBLAST $B_{12}$ IN METHYLMALONIC ACIDURIA

Table 1. Cobalamins in cultured fibroblasts from control subjects and patients with methylmalonic aciduria: Effect of hydroxocobalamin added to growth medium ${ }^{1}$

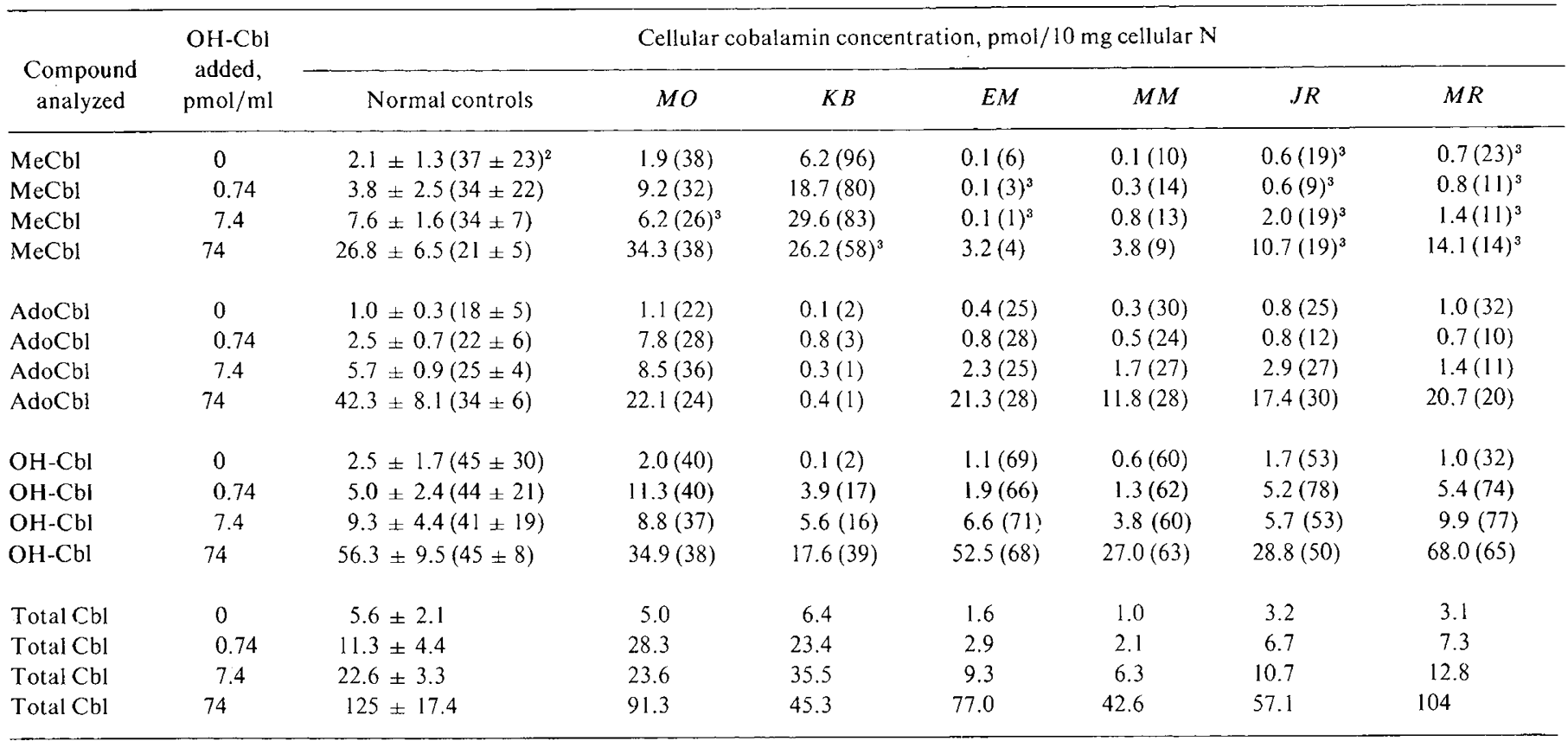

${ }^{1}$ Fibroblasts were grown as described under Methods. After 5 days of growth in the dark in the presence of the specified added concentrations of hydroxocobalamin $(\mathrm{OH}-\mathrm{Cbl})$, the cells were harvested in red light and analyzed for cobalamins. The growth medium without added $\mathrm{OH}$-Cbl contained 0.04 $0.07 \mathrm{pmol} / \mathrm{ml}$ cobalamin. MeCbl: methylcobalamin; AdoCbl: adenosylcobalamin.

${ }^{2}$ Mean (for three cell lines) \pm 1 SD. Values in parentheses are percentages of total cobalamin values.

${ }^{3}$ In these experiments, the sums of the individual components are less than the totals. The differences were contributed by cyanocobalamin.

(containing $0.02 \mathrm{pmol}$ cobalamin $/ \mathrm{ml}$, with $\left[{ }^{57} \mathrm{Co}\right] \mathrm{OH}-\mathrm{Cbl}$ added to $0.10-0.15 \mathrm{pmol} / \mathrm{ml}$ ), these workers found concentrations of $\mathrm{MeCbl}$ and $\mathrm{AdoCbl}$ of 0.44 and $0.16 \mathrm{pmol} / \mathrm{g}$ wet weight of cells. As pointed out in the original description of the radioisotopic method, these values represent only newly synthesized coenzymes, and on this account would have underestimated total cellular coenzyme concentrations by as much as twofold under the conditions used, since the unlabeled cobalamins present in the cells at the start of these experiments would have gone undetected. Furthermore, it is possible the cells used the unlabeled cobalamin endogenously present in the growth medium (and probably bound to proteins) in preference to the exogenously added (possibly unbound) $\left[{ }^{57} \mathrm{Co}\right] \mathrm{OH}-\mathrm{Cbl}$. Such preferential use of the endogenous cobalamin would have led to additional underestimation of $\mathrm{MeCbl}$ and $\mathrm{AdoCbl}$ synthesis (16). If these factors are taken into consideration, the two methods give estimates of total cellular $\mathrm{MeCbl}$ and AdoCbl which are in reasonable agreement. Both values for AdoCbl are below the concentration of $3.7 \mathrm{pmol} / \mathrm{g}$ wet weight of fibroblasts, obtained by Rosenberg et al. (28) using an enzymic assay with extracts of cells grown in a medium containing $0.02 \mathrm{pmol} / \mathrm{ml}$ cobalamin. The reason or reasons for the discrepancy between our results and those of Rosenberg et al. are not clear. Poor recovery of $\mathrm{AdoCbl}$ is not likely to the responsible, since the yields of tissue cobalamins analyzed by the present method are $80 \%$ or better $(87 \% \pm 4.2 \mathrm{SEM})$.

The concentrations of $\mathrm{MeCbl}$ and $\mathrm{AdoCbl}$ in fibroblasts grown in our basal medium are not particularly high when compared with the adult human tissues richest in these compounds. For example, liver, kidney, spleen, brain, and pituitary contain from 5-35 pmol $\mathrm{MeCbl} / \mathrm{g}$ wet weight, and from 17-414 pmol AdoCbl/g (12). In the cultured fibroblasts, $\mathrm{MeCbl}$ is present at higher concentrations than is AdoCbl. In this respect, these cells differ in general from adult human tissues (in which AdoCbl is the major cobalamin (11)), but resemble fetal tissues. $\mathrm{MeCbl}$ is the major cobalamin in fetal liver, kidney, spleen, and brain (11). It should be realized, also, that is is extremely difficult to relate the cobalamin concentrations found in the present experiments to the concentrations which might exist in fibroblasts in vivo. Not only is the concentration of cobalamin in the interstitial fluid unknown, but cellular uptake of cobalamins in vivo may well be markedly facilitated by binding proteins not present in the growth medium used in the present experiments $(1,2,4,7,26,27,32,33)$.

In gel-filtered extracts of normal control human fibroblasts grown in our basal medium, about $50 \%$ of the enzyme, 5-methyltetrahydrofolate-homocysteine methyltransferase, is found as an apoenzyme activatable by in vitro addition of $\mathrm{MeCbl}$, and about $50 \%$ in the form of a holoenzyme (25). The latter may already be complexed to a cobalamin, either $\mathrm{MeCbl}$ or a demethylated derivative which would be recovered in our assay as $\mathrm{OH}-\mathrm{Cbl}$. The present results indicate that under basal conditions cellular $\mathrm{Cbl}$ may be present in such low concentrations as to be limiting in holoenzyme formation. The $10^{8}$ fibroblasts which contain 0.67 pmol $\mathrm{MeCbl}$ and $0.88 \mathrm{pmol} \mathrm{OH}-\mathrm{Cbl}$ (Fig. 1) would yield approximately $15 \mathrm{mg}$ soluble protein (31). Even if the methyltransferase has a molecular weight as high as $10^{6}$, and represents no more than one part in $10^{4}$ of the soluble cellular protein, this enzyme would be present in amounts stoichiometric with $\mathrm{MeCbl}+$ $\mathrm{OH}-\mathrm{Cbl}$. If the enzyme is smaller, or if it represents a higher portion of the protein, the methyltransferase will exceed these cobalamins. This line of reasoning suggests that most, perhaps all, of the fibroblast $\mathrm{MeCbl}$ will normally be complexed to methyltransferase apoenzyme. Perhaps a major portion of the material recoverable as $\mathrm{OH}-\mathrm{Cbl}$ will be complexed also (34). Limitation of holoenzyme formation by available $\mathrm{Cbl}$ is compatible with the observations that as $\mathrm{OH}-\mathrm{Cbl}$ is increased in the growth medium, and brings about a 22 -fold increase in cellular $\mathrm{MeCbl}+\mathrm{OH}-\mathrm{Cbl}$ (Table 1, Fig. 1) holoenzyme comes to represent more than $90 \%$ of the total 5-methyltetrahydrofolate-homocysteine methyltransferase activity. Concomitantly there is a 2.5 -fold increase in the total amount of functional protein of this enzyme (25).

For fibroblasts cultured from patients with methylmalonic aciduria the present results for each patient are in agreement with the variety of evidence (reviewed above) which indicates that: $(I)$ $M O$ had a defect in formation of methylmalonyl-CoA mutase 


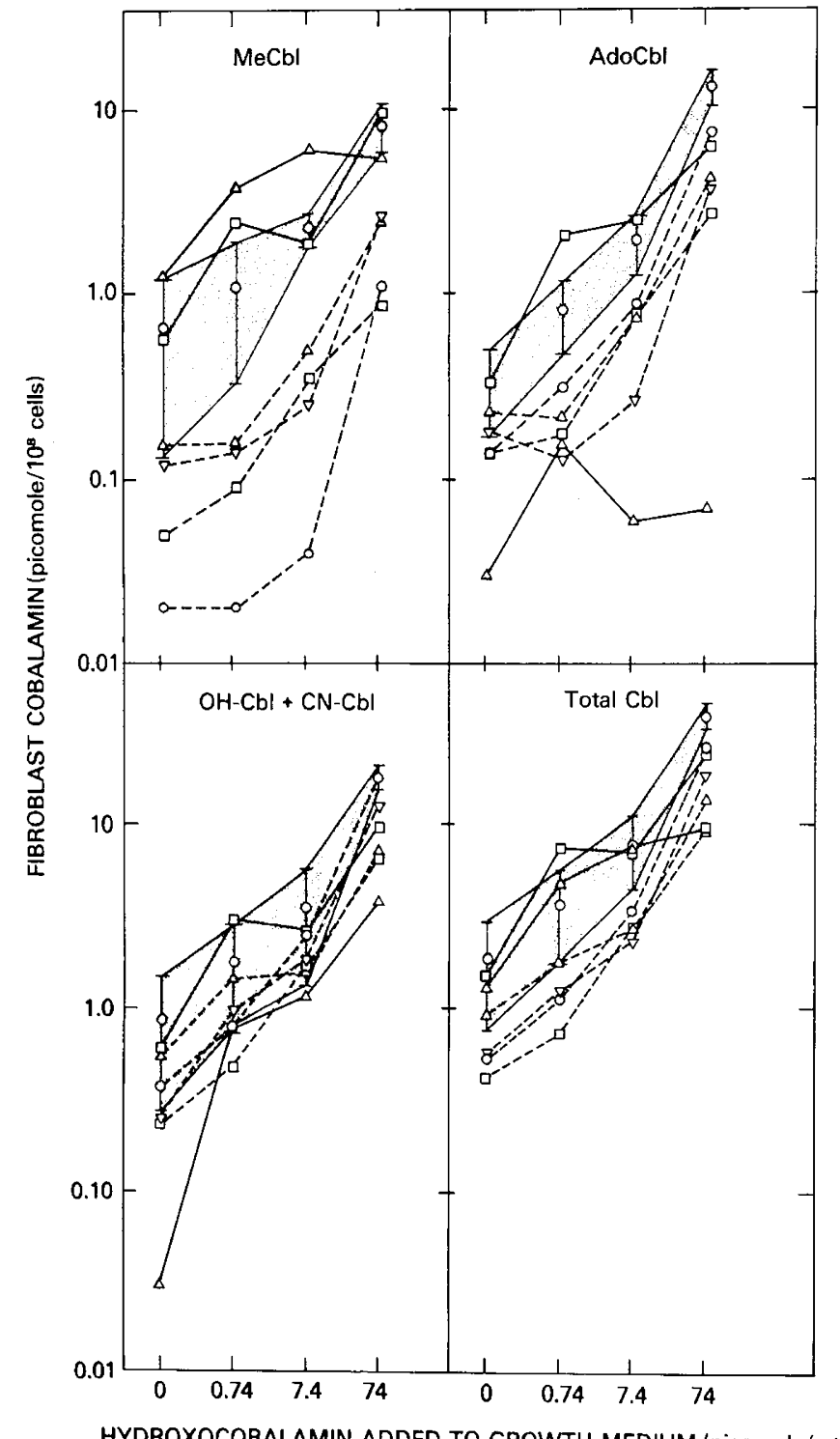

Fig. 1. Effect of hydroxocobalamin in growth medium upon cellular cobalamins of cultured fibroblasts. See legend to Table 1 for description of experimental conditions. Solid lines: $O$, mean value for three control lines ( $\pm 1 \mathrm{SD}$, indicated by vertical bars and shaded areas; $\square, M O ; \triangle, K B$ Dashed lines: $O, E M ; \square, M M ; \triangle, J R ; \quad, M R$. Because the ordinate is logarithmic, the plotted arithmetic means are not midway in the bars indicating standard deviations. $\mathrm{MeCbl}$ : methylcobalamin; $\mathrm{Ado} \mathrm{Cbl}$ : adenosylcobalamin; $\mathrm{OH}$-Cbl: hydroxocobalamin; $\mathrm{CN}$ - $\mathrm{Cbl}$ : cyanocobalamin Cbl: cobalamin.

apoenzyme but no abnormality of cobalamin metabolism; (2) $K B$ was unable to form AdoCbl, but could form at least normal amounts of $\mathrm{MeCbl}$; (3) $E M, M M, J R$, and $M R$ were unable to accumulate normal amounts of either $\mathrm{MeCbl}$ or AdoCbl. This is the first direct demonstration of such defects in $J R$ and $M R$ cells. Each of these four cell lines presumably has a lesion affecting a step in the cellular uptake or early metabolism of cobalamin which is involved in the formation of both $\mathrm{MeCbl}$ and AdoCbl. However, as has been pointed out previously, the available evidence does not permit exact definition of the specific lesion in any single case. Furthermore, it is possible that not each of these cell lines is affected at the same metabolic site (3).

One of the purposes of growing the fibroblasts at a range of $\mathrm{Cbl}$ concentrations was to investigate whether any particular $\mathrm{Cbl}$ concentration was especially useful in bringing out the metabolic abnormalities present in the mutant cell lines. In these experi- ments, deviations from normal appeared most strikingly in the mutant cells grown in medium containing $0.74-7.4 \mathrm{pmol} \mathrm{OH}-\mathrm{Cbl} /$ $\mathrm{ml}$. However, the most convincing results for any given cell line were obtained by examining the patterns of cellular cobalamins over the entire range investigated.

The data on the cobalamin contents of the four lines of fibroblasts comprising group $c$ suggest that in none of this group of patients was the metabolic block complete. For each cell line, the addition of $\mathrm{OH}-\mathrm{Cbl}$ to the growth medium led to rises of cellular $\mathrm{MeCbl}$ and $\mathrm{AdoCbl}$ to concentrations which were comparable with those found in control cells grown in the presence of lower amounts of cobalamin. These results correlate with the clinical observation that the methylmalonic aciduria of $J R$ was greatly decreased after treatment with high doses of $\mathrm{OH}-\mathrm{Cbl}(5)$. It has also been shown that fibroblasts from $E M$ grown in the presence of high concentrations of $\mathrm{OH}-\mathrm{Cbl}$ metabolized propionate at almost a normal rate and possessed a small amount of $N^{5}$-methyltetrahydrofolatehomocysteine methyltransferase holoenzyme (25).

In contrast, the inability of cells from $K B$ to accumulate AdoCbl showed no signs of being overcome by $\mathrm{OH}-\mathrm{Cbl}$ addition. Even at the highest concentration of this compound tested, $K B$ fibroblasts contained virtually no detectable AdoCbl (Table 1 and Fig. 1). This child received a large dose of OH-Cbl 12-18 hr before her death, but showed no clinical benefit. Unfortunately, because of the brief time involved, this trial must be regarded as inconclusive (18). Among the group of patients whose fibroblasts (and other tissues) do not accumulate $\mathrm{AdoCbl}$, most are clinically responsive to large doses of cobalamins, but some are not (21). Since clinical responsiveness of a genetically determined metabolic disease to vitamin therapy is likely to require the presence of at least a small residual activity of the affected enzyme (22), it would not be surprising if in some patients the lesion preventing AdoCbl formation was so complete that it could not be alleviated by increasing the available cobalamin substrate. The evidence suggests that $K B$ was such a patient.

Taken together, the findings reported here indicate that twodimensional chromatobioautography is useful in the study of patients with methylmalonic aciduria. Not only does this technique permit direct demonstration of defects in cobalamin metabolism but it allows, in addition, investigation of possible correlations between the responses of whole cells to cobalamin supplementation and the effectiveness of such compounds in the clinical treatment of patients.

\section{SUMMARY}

Two-dimensional chromatobioautography has been used to study the cellular contents of $\mathrm{OH}-\mathrm{Cbl}, \mathrm{CN}-\mathrm{Cbl}, \mathrm{MeCbl}$, and $\mathrm{AdoCbl}$ in several lines of fibroblasts cultured from normal control subjects and grown in the presence of increasing concentrations of $\mathrm{OH}-\mathrm{Cbl}$. These cells are unlike most adult human tissues, but similar to fetal tissues, in that $\mathrm{MeCbl}$ is the predominant alkylated cobalamin derivative. When grown in the presence of high concentrations of $\mathrm{OH}-\mathrm{Cbl}$, these normal fibroblasts were able to form increased amounts of both AdoCbl and $\mathrm{MeCbl}$. The low concentrations of cobalamins under basal conditions may limit the accumulation of 5-methyltetrahydrofolate-homocysteine methyltransferase holoenzyme.

Cobalamin concentrations and distributions were determined also in six lines of fibroblasts cultured from patients with various forms of methylmalonic aciduria. One line had no abnormality of cobalamin metabolism, but was defective in formation of methylmalonyl-CoA mutase apoenzyme. One line accumulated virtually no AdoCbl, but did form at least normal amounts of MeCbl. Four cell lines did not accumulate normal amounts of either AdoCbl or $\mathrm{MeCbl}$. The responses of these mutant cell lines to growth in the presence of high concentrations of $\mathrm{OH}-\mathrm{Cbl}$ correlate with the clinical responsiveness of at least some of the patients in question to treatment with cobalamins. 


\section{REFERENCES AND NOTES}

1. Cooper, B. A.: Equilibrium of $\mathbf{B}_{12}$-binding proteins between transudates and plasma in man; evidence that transcobalamin 2 in vivo is smaller than albumin. Biochim. Biophys. Acta, 336: 270 (1974).

2. Cooper, B. A., and Paranchych, W.: Selective uptake of specifically bound cobalt-58 vitamin $B_{12}$ by human and mouse tumour cells. Nature, 191: 393 (1961).

3. Dillon, M. J., England, J. M., Gompertz, D., Goodey, P. A., Grant, D. B., Hussein, H. A.-A., Linnell, J. C., Matthews, D. M., Mudd, S. H., Newns, G. H., Seakins, J. W. T., Uhlendorf, B. W., and Wise, I. J.: Mental retardation, megaloblastic anaemia, methylnıalonic aciduria, and abnormal homocysteine metabolism due to an error in $B_{12}$ metabolism. Clin. Sci. Mol. Med., 47: 43 (1974)

4. Finkler, A. E., and Hall, C. A.: Nature of the relationship between vitamin $B_{12}$ binding and cell uptake. Arch. Biochem. Biophys., 120: 79 (1967).

5. Goodman, S. I., Keyser, A. J., Mudd, S. H., Schulman, J. D., Turse, H., and Lewy, $J$.: Responsiveness of congenital methylmalonic aciduria to derivatives of vitamin $B_{12}$. Pediat. Res., 6: 138 (1972).

6. Goodman, S. I., Moe, P. G., Hammond, K. B., Mudd, S. H., and Uhlendorf, B W.: Homocystinuria with methylmalonic aciduria: Two cases in a sibship. Biochem. Med., 4: 500 (1970).

7. Hakami, N., Neiman, P. E., Canellos, G. P., and Lazerson, J.: Neonatal megaloblastic anemia due to inherited transcobalamin II deficiency in two siblings. N. Engl. J. Med., 285: 1163 (1971).

8. Hill, H. Z., and Goodman, S. I.: Detection of inborn errors of metabolism. II Defects in propionic acid metabolism. Clin. Genet., 6: 73 (1974).

9. Kamalgharam, A.: Personal communication.

10. Levy, H. L., Mudd, S. H., Schulman, J. D., Dreyfus, P. M., and Abeles, R. H.: A derangement in $B_{12}$ metabolism associated with homocystinemia, cystathioninemia, hypomethioninemia and methylmalonic aciduria. Amer. J. Med. 48: $390(1970)$

11. Linnell, J. C.: The fate of cobalamins in vivo. In: B. M. Babior: Cobalamin Biochemistry and Pathophysiology, p. 287 (John Wiley \& Sons, New York, 1975).

12. Linnell, J. C., Hoffbrand, A. V., Hussein, H. A.-A., Wise, I. J., and Matthews, D. M.: Tissue distribution of coenzyme and other forms of vitamin $B_{12}$ in control subjects and patients with pernicious anaemia. Clin. Sci. Mol. Med. 46: 163 (1974).

13. Linnell, J. C., Hoffbrand, A. V., Peters, T. J., and Matthews, D. M. Chromatographic and bioautographic estimation of plasma cobalamins in various disturbances of vitamin $B_{12}$ metabolism. Clin. Sci., 40: 1 (1971).

14. Linnell, J. C., Hussein, H. A.-A., and Matthews, D. M. A two-dimensional chromato-bioautographic method for complete separation of individual plasma cobalamins. J. Clin. Pathol. 23: 820 (1970).

15. Mahoney, M. J., Hart, A. C. Steen, V. D., and Rosenberg, L. E.: Methylmalonicacidemia: Biochemical heterogeneity in defects of 5 -deoxyadenosylcobalamin synthesis. Proc. Natl. Acad. Sci. U. S. A., 72: 2799 (1975).

16. Mahoney, M. J., and Rosenberg, L. E.: Synthesis of cobalamin coenzymes by human cells in tissue culture. J. Lab. Clin. Med., 78: 302 (1971).

17. Mahoney, M. J., Rosenberg, L. E., Mudd, S. H., and Uhlendorf, B. W.: Defective metabolism of vitamin $B_{12}$ in fibrobalsts from children with methylmalonicaciduria. Biochem. Biophys. Res. Commun., 44: 375 (1971).

18. Martin, M.: Personal communication

19. Matthews, D. M., Gunasegaram, R., and Linnell, J. C.: Results with radioisotopic assay of serum $B_{12}$ using serum binding agent. J. Clin. Pathol (London), 20: 683 (1967)

20. Morrow, G., III, Barness, L. A., Cardinale, G. J., Abeles, R. H., and Flaks, J. G.: Congenital methylmalonicacidemia: Enzymatic evidence for two form of the disease. Proc. Natl. Acad. Sci. U. S. A., 63: 191 (1969).

21. Morrow, G., III, Mahoney, M. J., Mathews, C., and Lebowitz, J.: Studies of methylmalonyl coenzyme A carbonylmutase activity in methylmalonic acidemia. I. Correlation of clinical, hepatic, and fibroblast data. Pediat. Res., 9 $641(1975)$.
22. Mudd, S. H.: Vitamin-responsive genetic disease. J. Clin. Pathol., 27, Suppl. (Roy. Coll. Pathol.), 8: 38 (1974)

23. Mudd, S. H., Levy, H. L., and Abeles, R. H.: A derangement in $B_{12}$ metabolism leading to homocystinemia, cystathioninemia, and methylmalonic aciduria. Biochem. Biophys. Res. Commun., 35: 121 (1969).

24. Mudd, S. H., Levy, H. L., and Morrow, G., III: Deranged $B_{12}$ metabolism: Effects on sulfur amino acid metabolism. Biochem. Med., 4: 193 (1970).

25. Mudd, S. H., Uhlendorf, B. W., Hinds, K. R., and Levy, H. L.: Deranged $B_{12}$ metabolism: Studies of fibroblasts grown in tissue culture. Biochem. Med., 4: 215 (1970)

26. Paranchych, W., and Cooper, B. A.: Factors influencing the uptake of cyanocobalamin (vitamin $B_{12}$ ) by Ehrlich ascites carcinoma cells. Biochim. Biophys. Acta, 60: 393 (1962).

27. Rosenberg, L. E., Lilljequist, A., and Allen, R. H.: Transcobalamin IIfacilitated uptake of vitamin $B_{12}$ by cultured fibroblasts: Studies in methylmalonicaciduria. J. Clin. Invest., 52: 69a (1973).

28. Rosenberg, L. E., Lilljeqvist, A., Hsia, Y. E., and Rosenbloom, F. M.: Vitamin $B_{12}$ dependent methylmalonicaciduria: Defective $B_{12}$ metabolism in cultured fibroblasts. Biochem. Biophys. Res. Commun., 37: 607 (1969).

29. Taylor, R. T., Hanna, M. L., and Hutton, J. L.: 5-Methyltetrahydrofolate homocysteine cobalamin methyltransferase in human bone marrow and its relationship to pernicious anemia. Arch. Biochem. Biophys., 165: 787 (1974).

30. Technicon Corporation Bulletin no. 461a: An automated micro-Kjeldahl method for estimating total nitrogen.

31. Uhlendorf, B. W., and Mudd, S. H: Cystathionine synthase in tissue culture derived from human skin: Enzyme defect in homocystinuria. Science, 160: 1007 (1968).

32. Wickramsinghe, S. N., England, J. M., Saunders, J. E., and Down, M. C.: Role of transcobalamins I, II, and III in the transfer of vitamin $B_{12}$ to human bone marrow cells in vitro. Acta Haematol. 59: 89 (1975).

33. A sample of fetal calf serum was found to have a relatively high unsaturated TC O-like cobalamin binding protein, 10 times as much TC I-like protein and one-eighth as much TC II-like protein as compared with normal human serum (J. M. England and M. C. Down, personal communication to the authors).

34. The same conclusion is supported by calculations based on the measured activity of 5-methyltetrahydrofolate-homocysteine methyltransferase. Extracts of normal fibroblasts grown in our basal medium have a mean holoenzyme specific activity at $37^{\circ}$ of $4.2 \mathrm{nmol}$ methionine formed $/ \mathrm{mg}$ soluble protein $/ \mathrm{hr}$ (17), or $70 \mathrm{pmol}$ methionine $/ \mathrm{mg}$ soluble protein $/ \mathrm{min}$. Taylor et al. (29) have pointed out that both the bacterial and the mammalian methyltransferase, assayed under optimal conditions at $37^{\circ}$, have catalytic turnover numbers of 600.900 $\mathrm{pmol}$ methionine formed/minute/pmol of enzyme-bound $\mathrm{Cbl}$. Taking a mean turnover number of 750 , this suggests that the fibroblast extracts contain at least $70 / 750=0.09 \mathrm{pmol}$ enzyme-bound $\mathrm{Cbl} / \mathrm{mg}$ soluble protein. As pointed out above, the total $\mathrm{MeCbl}+\mathrm{OH}-\mathrm{Cbl}$ of these cells is $(0.67+0.88) /(15)=$ $0.10 \mathrm{pmol} / \mathrm{mg}$ soluble protein. Thus, the major portions of these cobalamins may exist in the fibroblasts complexed to the methyltransferase. Taylor and coworkers (29) have recently noted a similar agreement between the $\mathrm{Cbl}$ content of human bone marrow cells and the 5-methyltetrahydrofolatehomocysteine methyltransferase activity of these cells.

35. The authors wish to thank Dr. Malcolm Martin for sending us tissues and a skin biopsy from patient $K B$, Dr. Stephen Goodman for helpful discussions, and Drs. Grant Morrow III, Maurice Mahoney, and S. N. Wickramsinghe and their colleagues, for permitting us to read publications in press. We are grateful to Dr. A. Kamalgharam of the Department of Biochemistry. Imperial College, London, for arranging estimations of total nitrogen which were carried out by Mr. M. Vivekananda-Rajah. Financial support from the Wellcome Trust is gratefully acknowledged.

36. Requests for reprints should be addressed to either: J. C. Linnell, Department of Experimental Chemical Pathology, The Vincent Square Laboratories of Westminster Hospital, 124 Vauxhall Bridge Road, London SWIV 2RH (England), or S. Harvey Mudd, National Institute of Mental Health, BIdg. 32A, Rm. 101, 9000 Rockville Pike, Bethesda, Md. 20014 (USA)

37. Accepted for publication October 31, 1975 